International Journal of Instruction e-ISSN: 1308-1470 • www.e-iji.net
April 2019•Vol.12, No.2

p-ISSN: 1694-609X

pp. 243-258

Received: 14/10/2018

Revision: 15/01/2019

Accepted: 27/01/2019

OnlineFirst: 07/03/2019

\title{
Development and Validation of Students' Perception on Learning by Questioning Scale in Physics
}

\section{Nadi Suprapto}

Dr., Universitas Negeri Surabaya, Department of Physics, Surabaya, Indonesia, nadisuprapto@unesa.ac.id

The aim of the study was describing the development and validation of students' perception on learning by questioning (LBQ) scale in physics. Research and Development $(\mathrm{R} \& \mathrm{D})$ design was utilized in the research method. The number of senior high school students involved in the research were 224 students, composed of 95 boys (42.41\%) and 129 girls (57.59\%) from Indonesia. The instrument used for this study was the questionnaire of students' perception on LBQ. Analysis of data used SPSS 21 and AMOS 21, which consisted of identifying the factor structure through an exploratory factor analysis (EFA), estimating each dimension's internal consistency reliability coefficients, and cross-validating through a confirmatory factor analysis (CFA). The research obtained findings: (a) the construct validities and reliabilities of the students' perception on LBQ was varying from .577 and .901 with reliability Cronbach's $\alpha$ was .74 and the total variance explained was $57.99 \%$, (b) the result of CFA determined the parameters such as RMSEA, GFI, AGFI, RMR, CFI, NFI, and IFI of the structural model of students' perception on LBQ, which may be considered an acceptable model.

Keywords: Indonesia, physics, learning by questioning, students' perception, physics

\section{INTRODUCTION}

Questioning is "an ability that can be acquired and improved through education, rather than a distinctive quality" (Mucher, 2007). It is the most frequently utilized as an instructional strategy. Some previous researchers underlined the importance of questioning in teaching and learning process (such as Almeida, 2010; Chin, 2006; Chin \& Osborne, 2008; Kawalkar \& Vijapurkar, 2011; Suprapto, Suliyanah, \& Admoko, 2013). In questioning learning strategies, teachers take responsibility in guiding students attains questioning and answering skills. However, if teachers pose an enormous number of questions, the questions posed are not varying in level. Therefore, questioning strategies should be managed appropriately.

Citation: Suprapto, N. (2019). Development and Validation of Students' Perception on Learning by Questioning Scale in Physics. International Journal of Instruction, 12(2), 242-258. https://doi.org/10.29333/iji.2019.12216a 
The finding on teacher's typical use of low-level questions has been confirmed at all educational levels, from basic elementary to college level (Almeida, 2012). However, few studies have concerned with the typical of questions in physics teaching, including literal, inferential, and inquiries metacognitive (Suprapto et al., 2013). Studying about physics questioning gives more benefits to student-teacher interactions in terms of communication skills. Particularly, physics teachers often promoted problem-solving but rarely emphasize the significance of orienting the problems and asking questions (Suprapto et al., 2013). They most pose a question to learners without orient them to this question. Thus, the difficulties in orienting students to the problem via a series of questions become the major issue in physics education in Indonesia. The successful among physics education teacher in posing questions supported the constructivism paradigm since while the students try to response questions or solve problems, they also inspired to make reasoning and to create another question.

The formulation of guiding questions is one of the most essential parts in learning activities; however, it is ignored in physics teaching (Suprapto et al., 2013). The kind of teachers' questions influences the nature of students' thinking as they involve in the process of generating scientific knowledge (Chin, 2006). Teacher while boosting and responding to students' ideas is purposed for deciding the lesson remained on the track (Kawalkar \& Vijapurkar, 2011). Questions are aimed to explore the physics topics by not only generating discussion but also stimulating reasoning (Suprapto, 2014).

In the specific case of Indonesia, students have little understanding of science-global issues and less in content, epistemic, and procedural knowledge on physics learning. Indonesian students also demonstrate less ability to explain phenomena scientifically, design and evaluate scientific inquiry, and interpret data logically (Suprapto, 2016a). Therefore, thinking skills of students remain at a low level. This situation is affected by the lack of teachers' competencies in developing assessment referring to higher-order thinking skills (HOTs) or cognitive-4 (analyzing) to cognitive-6 (creating) in cognitive level; teachers have competencies up to the third level or cognitive-3 (applying) (Basuki, Suyono, Widyastomo, \& Yuanita, 2011). To overcome this situation, Suprapto (2016a) suggested some points, including synergize teaching, learning and thinking by addressing HOTs, critical thinking, creative thinking, self-directed learning, and problem-solving in physics classes and enhance students' role in the process of learning. In essence, human beings or human nature (including learners) are thinkers based on its' nature of science. In every activity, learners always think about something; therefore a sequence of questions will support them to expect what they reflect in class.

The spirit of constructivism stimulates the research about a questioning process is the construction of the questions for reasoning. Indeed, "students or learners who tried to answer questions or solve problems, they are also expected to be motivated to create questions" (Suprapto, 2014). Based on the author' experiences while guiding university students of physics learning simulation, workshop, and micro teaching of teaching practice program via course of - Program Pengelolaan Pembelajaran - and direct observations in school indicated that "most teachers were not good in orienting to the physics problem, but just giving problem or question to their students seems to be a crucial problem in learning physics" (Suprapto et al., 2013; Suprapto, 2014). 
On the other hand, the study about perception on specific pedagogic variables (such as these key phrases: "attitudes towards...", "conception of...", "opinion on...", "perception on....") have been concerned by previous researchers either through qualitative study (Akınoğlu, 2017; Almeida, 2012) or quantitative study (Ghanizadeh \& Jahedizadeh, 2017; Polat, 2017, Suprapto, 2016b; Uzuntiryaki \& Aydın, 2009). This study focused on other pedagogic variables, specifically on students' perception on learning by questioning (LBQ).

\section{CONTEXT AND LITERATURE REVIEW}

\section{Learning by Questioning (LBQ)}

The questioning cycle is a systematic diagram for utilizing questions to encourage students to consider diverse ideas and to collect information about student's knowledge (Elder \& Paul, 2007). It includes seven phases (see Figure 1): "(1) establishing lesson goals and guiding questions, (2) planning the question, (3) asking the question, \#allowing wait time, (4) listening to the student's response, (5) assessing the student's response, (6) following up the student's response with another question, and (7) replanning based on student's response" (Fusco, 2012).

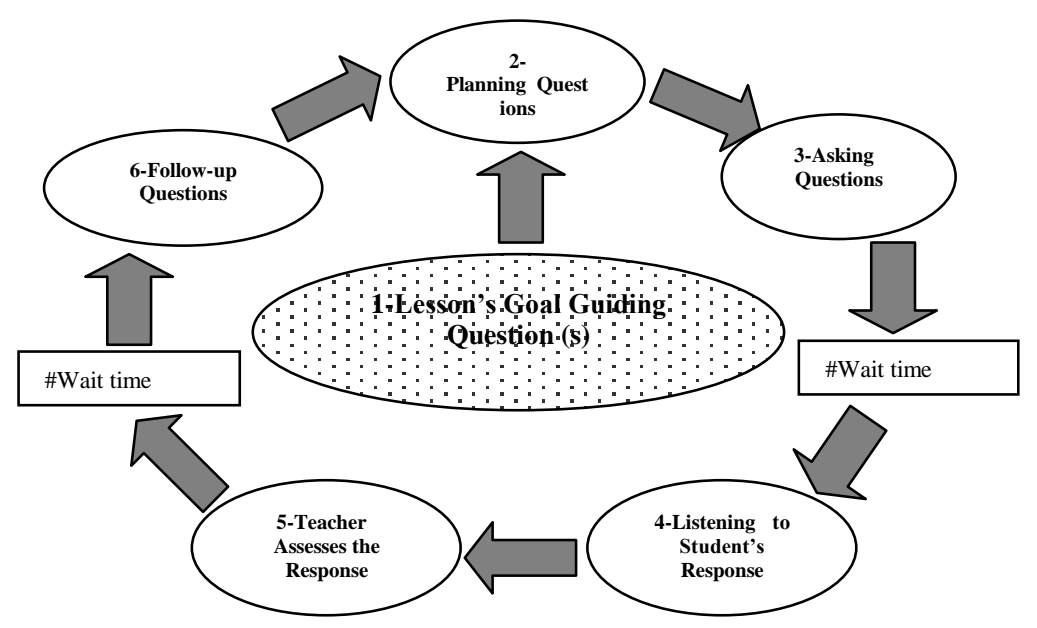

Figure 1

Questioning Cycle (modified from Fusco, 2012; Suprapto et al., 2013)

From a sequence of questioning on learning, this study dedicated to learning by questioning (LBQ) model that adopted from questioning cycle from Fusco (2012) (see Figure 1). Questioning cycle is "the way to gain an active learning as well as Dewey ideas that learning should be an enthusiastic, reflective process, one that engages student's thinking about real issues and ideas" (Fusco, 2012). This cycle is used to facilitate a classroom environment that supports the students to propose ideas and to ask a meaningful question about learning. However, according to Piaget through cognitive development theory, thinking skills can be already seen from the time when the students 
beyond the "formal operations" stage in junior high school, although it less pronounced (Slavin, 1997). The most characteristics of formal operation include abstract thinking, deductive reasoning, formal reasoning, generalizations, problem-solving, and questioning. The study by Suprapto (2014) indicated that most the high-school students (HSSs) could achieve these characteristics. Therefore, the research that focused on HSSs' questioning is more observable and measurable.

\section{Students' Perception on LBQ}

Rowe (1986) found at least eight dimensions of the influence by wait time as part of questioning cycle to the students: student's responses and inferences, student achievement, participating voluntarily in discussions, hypothetical thinking, disciplinary and student exchanges, and student confidence. In Rowe's study, "the length of student response's increases between $300 \%$ and $700 \%$, in some cases more, depends on the study; more inferences are supported by evidence and logical argument and the incidence of speculative thinking increases; the number of questions asked by student's increases; the number of experiments they propose increases; student-student exchanges also increase and failures to respond decrease; disciplinal moves to decrease".

Moreover, Martino and Maher (1999) underlined that teacher question could promote an understanding, justification, generalization, and critical thinking. They found a strong relationship between timely questions which can encounter learners to enhance their understanding. Additionally, Alexander et al. (2010) underlined critical thinking as influenced by teachers questioning. In a questioning cycle classroom, students are encouraged to research ideas and questions that developed as they discuss topics. Motivated by their interests, becoming better thinkers and problem solvers, students are more likely to engage in the active construction of knowledge, to make real connections, and to remember what they learn (Fusco, 2012). In this study, therefore, the author simplify the dimension or factor of student perceptions on LBQ into three things, namely relating to the questions effect (responses, justification, inference, generalization, achievement, understanding), thinking-problem solving (hypothetical thinking, critical thinking, creative thinking, problem solving), and affective perception (confidence, participation, motivation, disciplinary, interest, student-exchanges). The summary of the domain of student's perception on LBQ is illustrated in Table 1.

Table 1

Dimension of Student's Perception on LBQ

\begin{tabular}{llll}
\hline \multicolumn{1}{c}{ Rowe (1986) } & $\begin{array}{c}\text { Martino \& } \\
\text { Maher (1999) }\end{array}$ & Fusco (2012) & \multicolumn{1}{c}{ This research } \\
\hline $\begin{array}{l}\text { Responses, Inferences, } \\
\text { Achievement }\end{array}$ & $\begin{array}{l}\text { Understanding } \\
\text { Justification, } \\
\text { Generalization }\end{array}$ & - & $\begin{array}{l}\text { Questions effect (QE) (responses, } \\
\text { justification, inference, generalization, } \\
\text { achievement, and understanding) }\end{array}$ \\
\hline Hypothetical thinking & $\begin{array}{l}\text { Critical } \\
\text { thinking }\end{array}$ & $\begin{array}{l}\text { Creative } \\
\text { thinking, } \\
\text { Problem-solving }\end{array}$ & $\begin{array}{l}\text { Thinking-Problem solving (TPS) } \\
\text { (hypothetical thinking, creative thinking, } \\
\text { critical thinking, and problem-solving) }\end{array}$ \\
\hline $\begin{array}{l}\text { Participation, } \\
\text { Disciplinary, Student- } \\
\text { exchanges, Confidence }\end{array}$ & - & $\begin{array}{l}\text { Motivation, } \\
\text { Interests }\end{array}$ & $\begin{array}{l}\text { Affective perception (AP) (confidence, } \\
\text { motivation, participation, and } \\
\text { disciplinary, interest, student-exchanges) }\end{array}$ \\
\hline
\end{tabular}


Based on the aforementioned rational, the researcher proposed learning by questioning in a learning package. Since questioning cycle activity shows the relationship between teacher and student response of questions, it is indispensable to know the students' perceptions on LBQ. By exploring students' perception on LBQ, the whole picture of perception on questioning including question effect, thinking process, problem-solving, and affective perception could be mapped. Therefore, the research questions were derived into twofold:

1) To what extent do the validity and the reliability of students' perception on learning by questioning scale?

To what extent do students' perception on learning by questioning in physics?

\section{METHOD}

\section{Research Design}

Research and Development (R \& D) design was utilized in the research method. By addressing an instrumental paradigm (planning-by-objectives) (Visscher-Voerman, Gustafson, \& Plomp, 1999), the research consisted of four stages. The first stage initiated by developing physics' learning materials with LBQ' strategy and followed by teaching and learning process. At the same time, the author developed a questionnaire of students' perception on LBQ. In the next step, an internal validation with facilitated by physics education experts. The final stage was spread out the questionnaire and collecting data. The last stage was the main point of the report in this research.

\section{Sample}

This study involved 224 senior high school students who were studying in physics classroom from three different clusters in East Java, Indonesia with purposive sampling. The distribution of the sample involved in the research is shown in Table 2.

Table 2

The Distribution of Sample $(\mathrm{N}=224)$

\begin{tabular}{lrr}
\hline Demographics background & $\mathrm{N}$ & $\%$ \\
\hline Gender & & \\
Male & 95 & 42.41 \\
Female & 129 & 57.59 \\
\hline School Cluster & & \\
A & 62 & 27.68 \\
B & 80 & 35.71 \\
C & 82 & 36.61 \\
\hline Total & 224 & 100.00 \\
\hline
\end{tabular}

\section{Procedure}

This research focuses on the domain of physics. In the beginning, Research and Development ( $R \&$ D) design was guidance in the research methodology. The study begins by developing learning materials involved of syllabi, lesson plans, student's books, student's worksheets and guidelines, LBQ assessment sheets, and rubrics then 
tests the effectiveness of these materials through classroom implementation. It has been reported from the preliminary research (Suprapto, 2014), LBQ's material examples for senior high school physics with topics: Newton Laws and the static fluid were produced that appropriate with the current Indonesian curriculum (K-13). After developing the valid physics learning materials, it was followed by the implementation them into three school cluster (A, B, C) of senior high-school students in East Java- Indonesia during spring semester 2016 .

\section{Instrument}

The instruments used in this study were the questionnaire of students' perception on LBQ (see Appendix). The questionnaire was developed by the author and checked for internal validation, including language and items construct by two physics education experts. The maximum score acceptable from the LBQ's scale was 72, and the minimum score acceptable was 18 . Accordingly, the perceptions on learning by questioning corresponding to the scores received were as follows:

- 54-72 points reflect an informed perception consistent with learning by questioning model.

- 36-54 points reflect transitional perception in accord with partially informed perceptions, or those that fail to provide reasons for justification.

- 18-36 points reflect naive perception on learning by questioning containing (mis)understanding or self-contradictory statements.

\section{Data Analysis}

Analysis of data used SPSS version 21 and AMOS version 21. This study used exploratory factor analysis (EFA) and confirmatory factor analysis (CFA) with same data with these reasons: "...since we're developing new measures we might need to use exploratory since it is the first test with data on that measurement instrument. We might also be able to use confirmatory because we've got these a priori hypothesized patterns" (Hurley et al., 1997: p 675). By doing so, three steps were followed throughout the analysis of data: “(a) pinpointing the factor structure of students' perception on learning by questioning through the use of exploratory factor analysis (EFA), (b) approximating each dimension's internal consistency by determining Cronbach's alpha, and (c) crossvalidating the analysis by use of confirmatory factor analysis (CFA)" (Brace, Kemp, \& Snelgar, 2006; Uzuntiryaki \& Aydın, 2009). By referring these steps, previously, the author determined whether the data were appropriate to perform an EFA through Kaiser-Meyer-Olkin (KMO) and Bartlett's test (Suprapto, 2016b; Suprapto, Chang, \& $\mathrm{Ku}, 2017)$. "The KMO Index and Bartlett's Sphericity Test were used in the study to determine the adequacy of the sample and to indicate whether or not the data fitted the factor analysis" (Suprapto \& Mursid, 2017). Data could be factorized if the KMO value is .50 or above (Field, 2009; Polat, 2017). Meanwhile, for the data to fit factor analysis, a sphericity test should be statistically significant. Cronbach's Alpha $(\alpha)$ coefficient was calculated for the internal consistency of the study. CFA has conducted to cross-validate the construct validity of the scale. It was noted that the cut-off of the loading factor was 
.40 (Stevens, 2002). Additionally, the acceptable indexes for CFA were $[\mathrm{X} 2 / \mathrm{df}<3$, $.05<\mathrm{RMSEA}<.10, .90<\mathrm{GFI}<.95, .85<\mathrm{AGFI}<.90$, and $.90<\mathrm{CFI}<.95]$, with referring to Joreskog \& Sorbom (1993); Kline (2005); and Suprapto \& Mursid (2017).

\section{FINDINGS}

\section{Exploratory factor analysis of students' perception on $\mathrm{LBQ}$ in physics}

The items of students' perception on learning by questioning used questionnaire, which consists of three factors or dimensions were derived from the previous literature, namely: question effect, thinking problem-solving, and affective perception (see Table 3 ) as well as the result of scree plot from SPSS 21 output (Figure 3). The KMO value was .812 and the result of Bartlett's test was significant $\left(X^{2}=1959.211, d f=153, \mathrm{p}<\right.$ $.001)$, designating that the data were appropriate for factor analysis and were fulfilled the criteria of Field (2009) and Polat (2017).

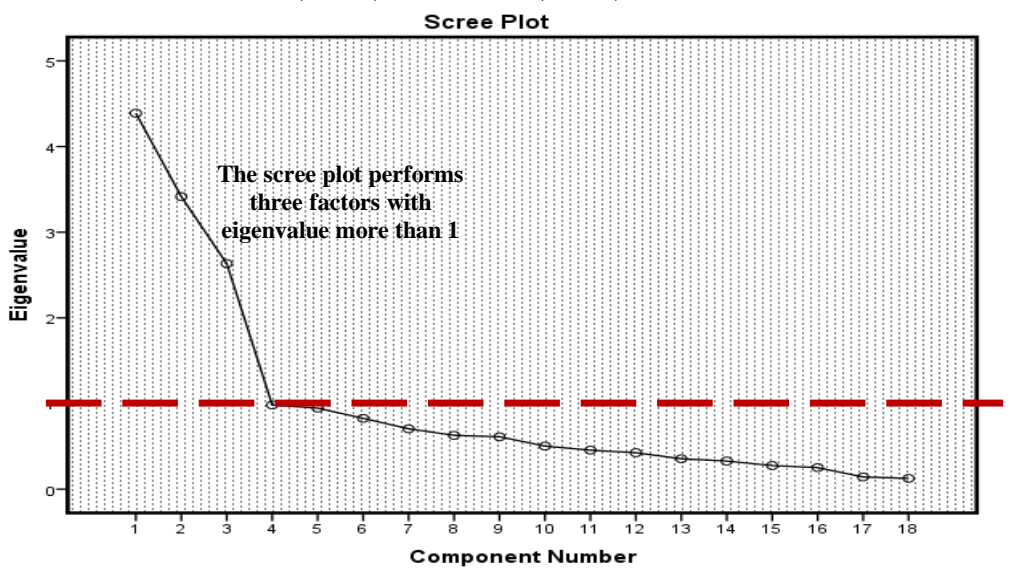

Figure 3

Scree Plot of the Questionnaire of Students' Perception on LBQ

Table 3 presents the descriptive statistics (means and standard deviations) of the factors of students' perception on LBQ. Each factor/ dimension consisted of six items (see Appendix). The mean ranged from 3.18 to 3.56 with the mean average was 3.36 . Thinking-Problem solving (TPS) was a factor that the most contribution to perception on LBQ. Totally, the questionnaire was composed of 18 four-point Likert items, with anchor ranging from strongly disagree (1) to strongly agree (4).

Table 3

Summary of Students' Perception About LBQ

\begin{tabular}{llll}
\hline Dimension / Factor & $N$ & $M$ & $S D$ \\
\hline Questions effect (QE) & 224 & 3.18 & 0.48 \\
\hline Thinking-Problem solving (TPS) & 224 & 3.56 & 0.45 \\
\hline Affective perception (AP) & 224 & 3.34 & 0.51 \\
\hline Total & & 3.36 & 0.28 \\
\hline
\end{tabular}


Table 4 shows the construct validities and reliabilities of the students' perception on LBQ. Factor loading of students' perception on LBQ calculated to measure each factor was between .577 and .901 . Meanwhile, totally variance explained was $57.99 \%$. This number is ubiquitous in behavioral science.

Table 4

Rotated Factor Loadings and Cronbach's Alpha of Students' Perception About LBQ

\begin{tabular}{|c|c|c|c|}
\hline Factors and items & $\lambda$ & $\%$ & $\alpha$ \\
\hline F1. Questions Effect (QE) & & 17.31 & .81 \\
\hline $\begin{array}{l}\text { 1. Implementation of the LBQ's strategy in Physics makes me more } \\
\text { active and responsive in the learning process }\end{array}$ & .722 & & \\
\hline $\begin{array}{l}\text { 2. Learning physics with LBQ's strategy makes me easier to give } \\
\text { justification about physics concepts }\end{array}$ & .872 & & \\
\hline $\begin{array}{l}\text { 3. Learning physics with LBQ's strategy helps me easier to make } \\
\text { inferences of physics concepts }\end{array}$ & .720 & & \\
\hline $\begin{array}{l}\text { 4. Learning physics with LBQ's strategy makes me easier to make a } \\
\text { generalization of physics concepts }\end{array}$ & .738 & & \\
\hline $\begin{array}{l}\text { 5. Implementation of the LBQ's strategy in Physics contribute to } \\
\text { student achievement }\end{array}$ & .624 & & \\
\hline $\begin{array}{l}\text { 6. Learning physics with LBQ's strategy makes me easier to understand } \\
\text { the physics concepts }\end{array}$ & .595 & & \\
\hline F2. Thinking-Problem Solving (TPS) & & 20.49 & .86 \\
\hline $\begin{array}{l}\text { 7. Learning physics with LBQ's strategy helps me easier to give } \\
\text { hypothetical thinking }\end{array}$ & .674 & & \\
\hline $\begin{array}{l}\text { 8. Learning physics with LBQ's strategy helps me easier to perform } \\
\text { critical thinking }\end{array}$ & .805 & & \\
\hline $\begin{array}{l}\text { 9. Learning physics with LBQ's strategy helps me easier to perform } \\
\text { creative thinking }\end{array}$ & .897 & & \\
\hline $\begin{array}{l}\text { 10. Learning physics with LBQ's strategy makes me easier to work on the } \\
\text { problems and tasks set by the teacher }\end{array}$ & .577 & & \\
\hline $\begin{array}{l}\text { 11. Learning physics with LBQ's strategy helps me easier in problem- } \\
\text { solving activities }\end{array}$ & .742 & & \\
\hline 12. Learning physics with LBQ's strategy deals with an authentic problem & .887 & & \\
\hline F3. Affective Perception (AP) & & 19.74 & .85 \\
\hline $\begin{array}{l}\text { 13. Learning physics with LBQ's strategy can improve my confidence in } \\
\text { learning physics }\end{array}$ & .596 & & \\
\hline $\begin{array}{l}\text { 14. Learning physics with LBQ's strategy can generate interest in learning } \\
\text { physics }\end{array}$ & .689 & & \\
\hline $\begin{array}{l}\text { 15. Learning physics with LBQ's strategy can increase my participation } \\
\text { in class }\end{array}$ & .901 & & \\
\hline $\begin{array}{l}\text { 16. Learning physics with LBQ's strategy makes me more motivated to } \\
\text { learn and to achieve }\end{array}$ & .816 & & \\
\hline $\begin{array}{l}\text { 17. Learning physics with LBQ's strategy makes me more discipline in } \\
\text { learning physics }\end{array}$ & .693 & & \\
\hline 18. Learning physics with LBQ's strategy provides us student-exchanges & .781 & & \\
\hline Overall & & 57.99 & .74 \\
\hline
\end{tabular}

$\lambda$, factor loading; $\alpha$, reliability coefficient

\section{Reliability analysis of instrument}

Analysis of reliabilities vis-à-vis internal consistency resulted coefficients of alpha were 0.81 for the QE, 0.86 for the TPS, and 0.85 for the AP, demonstrating satisfactory 
reliability. Likewise, the overall of Cronbach's $\alpha$ was .74. at the moderate level. It was noted that no items were deleted since each of them support a similar contribution to Cronbach's alpha coefficient if item deleted. Indeed, if item 1 was deleted, the Cronbach's alpha coefficient will reduce significantly as shown in Table 5.

Table 5

Items Statistics- Cronbach's Alpha if Item Deleted

\begin{tabular}{llllll}
\hline $\begin{array}{l}\text { Item } \\
1\end{array}$ & $\begin{array}{l}\text { Cronbach's alpha if } \\
\text { item deleted }\end{array}$ & Item & $\begin{array}{l}\text { Cronbach's alpha if } \\
\text { item deleted }\end{array}$ & Item & $\begin{array}{l}\text { Cronbach's alpha if } \\
\text { item deleted }\end{array}$ \\
\hline 2 & .621 & 7 & .732 & 13 & .732 \\
\hline 3 & .713 & 8 & .733 & 14 & .722 \\
\hline 4 & .719 & 9 & .730 & 15 & .724 \\
\hline 5 & .715 & 10 & .727 & 16 & .716 \\
\hline 6 & .721 & 11 & .728 & 17 & .740 \\
\hline
\end{tabular}

\section{Confirmatory factor analysis of students' perception on $L B Q$ in physics}

In an effort to fit the model from the 18-item students' perception on LBQ questionnaire, a CFA was utilized using the analysis of moment structures (AMOS) version 21. "The maximum likelihood estimation" technique was selected (Uzuntiryaki \& Aydin, 2009). Figure 4 depicts the model specification and the parameter estimates. The ratio of Chi-square $\left(\chi^{2}\right)$ and degree of freedom $(d f)$ obtained from CFA were 2.399 $(p<.001)$, it was less than 3.0 as an indicator for good fit index. In a CFA analysis, the value of RMSEA $(.05<R M S E A<.10)$ is an indicator of acceptable indexes (Kline (2005); Schermelleh-Engel, Moosbrugger, \& Müller (2003); and Suprapto \& Mursid (2017). The value of RMSEA in this research was .079, which could be well thought-out acceptable.

Additionally, the results of CFA determined GFI, AGFI, and RMR were $.859, .818$, and .032 , respectively. Accordingly, it can be asserted that the model-data fit was allowable. Meanwhile, the criteria for CFI (Comparative Fit Index), NFI (Normed Fit Index) and IFI (Incremental Fit Index) was .90, an indicator of a perfect fit between the model and the data obtaining (Joreskog \& Sorbom (1993); Kline (2005); and Suprapto \& Mursid (2017). The results of the analysis also determined CFI, NFI, IFI as .901, .843 and .902, respectively, which may be considered an acceptable model. Moreover, all parameters (especially, factor loadings) were proven to be significant, indicating a significant contribution of each item to the corresponding factor. Lastly, even though the correlations among the three factors were moderate but there were no specification errors nor were any additional modifications of the model specified. Thus, it can be asserted that there is a fit structure between the model attained from the CFA and the data. 


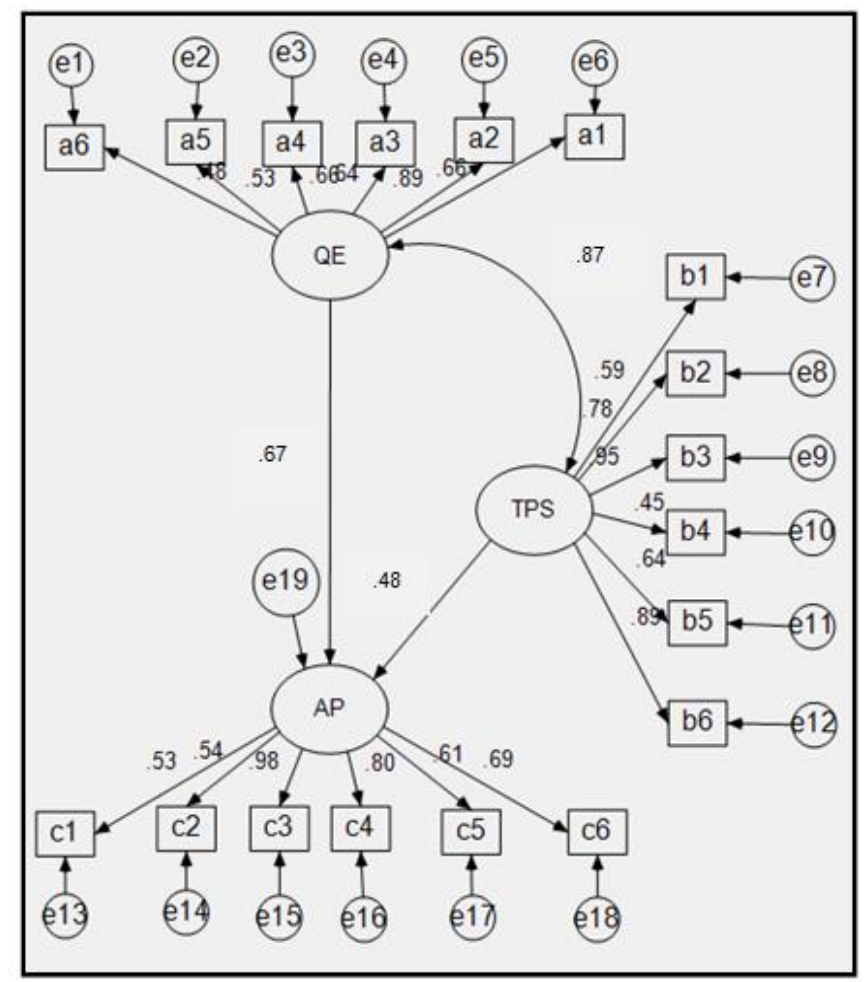

Figure 4

Structural Model of Students' Perception on LBQ [Root Mean Square Error Approximation=.079; Comparative Fit Index=.901; Incremental Fit Index=.902; $\mathrm{QE}=$ Question Effect; TPS=Thinking-Problem Solving; AP=Affective Perception].

\section{DISCUSSION}

As described in the research method, this research initiated by developing physics' learning materials with LBQ' strategy and implementing them through the teaching and learning process. To explore students' perception on LBQ, then the author developed a questionnaire of students' perception on LBQ to indicate the effectiveness of the learning strategy. Therefore, the focus of the research was to describe the extent of the validity and the reliability of the questionnaire and to explore the extent of students' perception on LBQ in physics learning.

Generally, the instrument was developed to fulfill the criteria of validity and reliability. However, there were some notes concerning the development and validation process. Considering the result of the construct validities and reliabilities of the students' perception on LBQ, even though factor loading of each factor were between .577 and .901 , but the overall Cronbach's was .74 (in moderate level). The logical reason is the author avoid "Cronbach's $\alpha$ if an item deleted" because as performed by Table 5, the 
range of $\alpha$ was .621 to .740 (in the small interval). Indeed, if item 1 will be deleted then the reliability decrease to .621 . So, this is the reason why the author kept the number of items. Then, the contribution of each factor to students' perception on LBQ gave Thinking-Problem Solving $($ TPS $)=20.49 \%$, Affective Perception $($ AP) $=19.74 \%$, and Questions Effect $(\mathrm{QE})=17.31 \%$, with total contributions were $57.99 \%$ of the students' perception on LBQ. The result of CFA determines RMSEA value is .079, GFI as .859, AGFI as .818, and RMR as .032. The results of the analysis resulted from CFI as .901, NFI as .843 and IFI as .902. All parameters indicated an acceptable model.

Moreover, from the structural model, question effect $(\mathrm{QE})$ and thinking-problem solving (TPS) have a role as predicting variable and affective perceptions (AP) as the predicted variable. The correlation between QE and TPS was .87. Among the three factors, students' thinking-problem solving contributed the most students' perception on learning by questioning (LBQ), followed by students' affective perception (AP). The last contribution was questioned effect (QE) itself. This result also confirmed the study by Alexander et al. (2010) who underlined critical thinking as influenced by teachers questioning. In a questioning cycle classroom, students are encouraged to research ideas and questions that developed as they discuss topics. The study also supported the finding of Martino and Maher (1999) who indicated that teacher question could promote an understanding, justification, and critical thinking. In other words, a strong relationship between timely questions which can encounter learners to improve their understanding was initiated. Additionally, QE predicted AP about .67 and TPS predicted AP about .48 in moderate level. This finding elaborated the study by Fusco (2012) who signaled that an affective perception including confidence, participation, motivation, disciplinary, interest, student-exchanges, can be stimulated by how students were thinking. Furthermore, motivated by their interests, becoming better thinkers and problem solvers, students are more expected to take part in the active construction of knowledge, to make real connections, and to remember what they learn.

In the implementation of LBQ strategy in teaching and learning process as part of this research covered three levels of questions: literal, inferential, and inquiries metacognitive. Literal question is "question that is often called closed-ended or used for final question and cover because this question requires an answer correct" (Fusco, 2012). Inferential question is "the open-ended because it is not just one answer from the students and they have a variety of reasons" (Fusco, 2012; Suprapto, 2014). Meanwhile, metacognitive level encourages students to describe and to imagine the process of their thinking. Accordingly, the high correlation between the factor of question effect (QE) and thinking-problem solving (TPS) can also be explained from the domain of question in term of domain of the knowledge. As we know, the domain of knowledge gradually leveled from - "factual knowledge, conceptual knowledge, procedural knowledge, and metacognitive knowledge" (Anderson \& Krathwohl, 2001). The metacognitive questions as the top level of question covered those literal and inferential questions in this study. It also considered the high cognitive levels (analyze-evaluate-create) (Basuki et al., 2011). 
Based on the findings and some drawbacks then can be written some implications throughout this study: 1) It is influential to check and re-examine the scale of questionnaire or instrument for the future research; 2) It is essential to consider not only the teachers' question but also the student's question for future research; 3) By using a questioning cycle, the teacher can determine the direction for forthcoming instruction for each student within the classroom; 4)Another way that teachers can assess the efficacy of their plan on LBQ is to think about the following suggested by Fusco (2012):

a. Do I use teacher-generated questions in all concepts?

b. How do I demonstrate that I appreciate and respect all authentic responses?

c. Do I provide real feedback to responses? How do I know that is effective?

d. How do I measure the gains that my students are achieving?

Additionally, the developing of scale should also consider the leveling of the question (literal, inferential, and inquiries metacognitive). Indeed, these types of questions could be a stand dimension or factor for further research. By doing so, the research about learning by questioning strategy become more specific and touch the inner part of teaching and learning process.

\section{CONCLUSION}

Considering the findings and discussion then can be summarized the conclusion from this study:

a. Regarding the first research question, "to what extent do the validity and the reliability of students' perception on learning by questioning scale?", then the following explanation is the answer.

The construct validities and reliabilities from EFA of the students' perception on $L B Q$ varied from .577 and .901 , with reliability Cronbach's $\alpha$ was .74 . The total variance explained with this factor structure was $57.99 \%$. The result of CFA determines all parameters indicated an acceptable model. Generally, it can be concluded that the Indonesian version of students' perception on learning by questioning $(L B Q)$ questionnaire had acceptable reliability and validity indices.

b. Turning to the second question, "to what extent do students' perception on learning by questioning (LBQ) in physics?", the explanation as follow. Among the three factors, students' thinking-problem solving contributed the most students' perception on learning by questioning (LBQ), followed by students' affective perception (AP). The last contribution was questions effect $(Q E)$ itself. We can see from either the mean among these three factors or the total variance explained. Moreover, from the structural model, question effect and thinking-problem solving have a role as predicting variable and affective perceptions as the predicted variable.

\section{ACKNOWLEDGMENT}

The author would like to thank Professor Te-Sheng Chang, through the course of "Questionnaire Design", when he pursued doctoral degree (2014-2017) at National Dong Hwa University-Taiwan, this paper was manifested. This research work was 
supported by Ristek-Dikti through the scheme of Decentralization Research with grant number: 022.70/UN.38.11-P/LT/2014.

\section{REFERENCES}

Akınoğlu, O. (2017). Pre-service teachers' metaphorical perceptions regarding the concept of curriculum. International Journal of Instruction, 10(2), 263-278. Retrieved from https://doi.org/10.12973/iji.2017.10217a

Alexander, M., E., Commander, N., Greenberg, D., \& Ward, T. (2010). Using the fourquestions technique to enhance critical thinking in online discussions. MERLOT Journal of Online Learning and Teaching, 6(2), 409-415.

Almeida, P. A. (2010). Classroom questioning: Teachers' perceptions and practices. Procedia Social and Behavioral Sciences, 2, 305-309.

Almeida, P. A. (2012). Can I ask questioning?. The importance of classroom questioning. Procedia Social and behavioral Sciences, 31, 634-638.

Anderson, L. W., \& Krathwohl, D. R. (Eds). (2001). A taxonomy for learning, teaching, and assessing: A revision of Bloom's taxonomy of educational objectives. New York, NY: Longman.

Basuki, I., Suyono, Widyastomo, H., \& Yuanita, L. (2011). Pemetaan dan pengembangan mutu pendidikan sekolah menengah atas di wilayah Indonesia barat [Mapping and developing of education quality of high school in Western Indonesia]. Surabaya, Indonesia: PPMP Grant Research Report, Lemlit UNESA.

Brace, N., Kemp, R. \& Snelgar, R. (2006). SPSS for Psychologists, 3rd ed. New York, NY: Palgrave MacMillan.

Chin, C. (2006). Classroom interaction in science: Teacher questioning and feedback to students' responses. International Journal of Science Education, 28(11), 1315-1346.

Chin, C., \& Osborne, J. (2008). Students' questions: A potential resource for teaching and learning science. Studies in Science Education, 44, 1-39.

Elder, L., \& Paul, R. (2007). Analytic thinking (How to take thinking apart and what to look for when you do). The Foundation for critical thinking. Retrieved from www.criticalthinking.org.

Field, A. (2009). Discovering Statistics Using SPSS. 3rd ed. London: Sage.

Fusco, E. (2012). Effective questioning strategies in the classroom. New York, NY: Teachers College, Columbia University.

Ghanizadeh, A., \& Jahedizadeh, S. (2017). Validating the Persian version of reflective thinking questionnaire and probing Iranian university students' reflective thinking and academic achievement. International Journal of Instruction, 10(3), 209-226. Retrieved from https://doi.org/10.12973/iji.2017.10314a 
Hurley, A. E., Scandura, T. A., Schriesheim, C. A., Brannick, M. T., Seers, A., Vandenberg, R. J., \& Williams, L. J. (1997). Exploratory and confirmatory factor analysis: Guidelines, issues, and alternatives. Journal of Organizational Behavior, 18, 667-683.

Joreskog, K. G., \& Sorbom, D. (1993). Lisrel 8: Structural equation modeling with the simplis command language. Hillsdale, NJ: Erlbaum Associates Publishers.

Kawalkar, A., \& Vijapurkar, J. (2011). Scaffolding science talk: The role of teachers' questions in the inquiry classroom. International Journal of Science Education, 11(1), $1-24$.

Kline, R. B. (2005). Principles and practice of structural equation modeling. New York, NY: The Guilford Press.

Martino, A., M., \& Maher, C., A. (1999). Teacher questioning to promote justification and generalization in mathematics: What research practice has taught us. Journal of Mathematical Behavior, 18(1), 53-78.

Mucher, S. (2007). Building a culture of evidence through professional development. The History Teacher, 40(2), 265-273.

Polat, M. (2017). Teachers' attitudes towards teaching English grammar: A scale development study. International Journal of Instruction, 10(4), 379-398. Retrieved from https://doi.org/10.12973/iji.2017.10422a

Rowe, M. B. (1986). Wait time: Slowing down may be a way of speeding up!. Journal of Teacher Education, 37(1), 43-50.

Schermelleh-Engel, K., Moosbrugger, H., \& Müller, H. (2003). Evaluating the fit of structural equation models: Tests of significance and descriptive goodness-of-fit measures. Methods of Psychological Research Online, 8(2), 23-74.

Slavin, R. E. (1997). Educational psychology (fourth edition). Massachusetts, MA: Allyn and Bacon Publishers.

Stevens, J. (2002). Applied multivariate statistics for the social sciences. Mahwah, NJ: Erlbaum.

Suprapto, N. (2014). Role of physics' questions on the improvement of thinking skills: A case of Indonesian student. International Journal of Education and Research, 2(12), 71-82.

Suprapto, N. (2016a). What should educational reform in Indonesia look like?: Learning from the PISA science scores of East-Asian countries and Singapore. AsiaPacific Forum Science Learning and Teaching, 17(2), 16.

Suprapto, N. (2016b). Students' attitudes towards STEM education: Voices from Indonesian junior high school. Journal of Turkish Science Education, 13(Special Issue), 75-87. 
Suprapto, N., Chang, T.-S., \& Ku, C.-H. (2017). Conception of learning physics and self-efficacy among Indonesian university students. Journal of Baltic Science Education, 16(1), 7-19.

Suprapto, N., \& Mursid, A. (2017). Pre-service teachers' attitudes toward teaching science and their science learning at Indonesia Open University. Turkish Online Journal of Distance Education, 18(4), 66-77.

Suprapto, N., Suliyanah, \& Admoko, S. (2013). Pembelajaran fisika di SMA melalui pertanyaan (Learning by Questioning) dan keterampilan berpikir. Jurnal Penelitian Fisika dan Aplikasinya, 3(2), 1-11.

Uzuntiryaki, U., \& Aydın, Y. Ç. (2009). Development and validation of chemistry selfefficacy scale for college students. Research in Science Education, 39(5), 539-551.

Visscher-Voerman, I., Gustafson, K., \& Plomp, T. (1999). Educational design and development: An overview of paradigms. In J. v. den Akker, R. M. Branch, K. Gustafson, N. Nieveen, \& T. Plomp, Design approaches and tools in education and training (pp. 15-28). Dordrecht: Springer Science+Business Media. 


\section{APPENDIX}

Directions:

Student's Perceptions on Learning by Questioning (LBQ) Questionnaire

1. In the questionnaire, there are eight teen statements. Consider carefully any statement in relation to material that you learned. Give an answer that really fits with your choice.

2. Consider each statement separately and determine the truth. Your answer should not be influenced by the response to the other statements.

3. There are four choices after statement: Strongly-Disagree (SD), Disagree (D), Agree (A), StronglyAgree (SA).

4. Record your responses on the answer sheet provided, with a tick $(\sqrt{ })$ mark.

Thanks a lot you.

Students' Perceptions on LBQ

\begin{tabular}{|c|c|c|c|c|c|c|}
\hline \multirow{3}{*}{ No } & \multirow{3}{*}{ Code } & \multirow{3}{*}{ Items } & \multicolumn{4}{|c|}{ Option } \\
\hline & & & SD & $\mathrm{D}$ & A & SA \\
\hline & & & 1 & 2 & 3 & 4 \\
\hline 1 & a1. & $\begin{array}{l}\text { Implementation of the LBQ's strategy in Physics } \\
\text { makes me more active and responsive in the learning } \\
\text { process. }\end{array}$ & & & & \\
\hline 2 & $\mathrm{a} 2$. & $\begin{array}{l}\text { Learning physics with LBQ's strategy makes me easier } \\
\text { to give justification about physics concepts. }\end{array}$ & & & & \\
\hline 3 & a3. & $\begin{array}{l}\text { Learning physics with LBQ's strategy helps me easier } \\
\text { to make inferences of physics concepts. }\end{array}$ & & & & \\
\hline 4 & a4. & $\begin{array}{l}\text { Learning physics with LBQ's strategy makes me easier } \\
\text { to make a generalization of physics concepts. }\end{array}$ & & & & \\
\hline 5 & a5. & $\begin{array}{l}\text { Implementation of the LBQ's strategy in Physics } \\
\text { contribute to student achievement. }\end{array}$ & & & & \\
\hline 6 & a6. & $\begin{array}{l}\text { Learning physics with LBQ's strategy makes me easier } \\
\text { to understand the physics concepts. }\end{array}$ & & & & \\
\hline 7 & b1. & $\begin{array}{l}\text { Learning physics with LBQ's strategy helps me easier } \\
\text { to give hypothetical thinking. }\end{array}$ & & & & \\
\hline 8 & b2. & $\begin{array}{l}\text { Learning physics with LBQ's strategy helps me easier } \\
\text { to perform critical thinking. }\end{array}$ & & & & \\
\hline 9 & b3. & $\begin{array}{l}\text { Learning physics with LBQ's strategy helps me easier } \\
\text { to perform creative thinking. }\end{array}$ & & & & \\
\hline 10 & b4. & $\begin{array}{l}\text { Learning physics with LBQ's strategy makes me easier } \\
\text { to work on the problems and tasks set by the teacher. }\end{array}$ & & & & \\
\hline 11 & b5. & $\begin{array}{l}\text { Learning physics with LBQ's strategy helps me easier } \\
\text { in problem-solving activities. }\end{array}$ & & & & \\
\hline 12 & b6. & $\begin{array}{l}\text { Learning physics with LBQ's strategy deals with an } \\
\text { authentic problem. }\end{array}$ & & & & \\
\hline 13 & $\mathrm{c} 1$. & $\begin{array}{l}\text { Learning physics with LBQ's strategy can improve my } \\
\text { confidence in learning physics. }\end{array}$ & & & & \\
\hline 14 & $\mathrm{c} 2$. & $\begin{array}{l}\text { Learning physics with LBQ's strategy can generate } \\
\text { interest in learning physics. }\end{array}$ & & & & \\
\hline 15 & c3. & $\begin{array}{l}\text { Learning physics with LBQ's strategy can increase my } \\
\text { participation in class. }\end{array}$ & & & & \\
\hline 16 & c4. & $\begin{array}{l}\text { Learning physics with LBQ's strategy makes me more } \\
\text { motivated to learn and to achieve. }\end{array}$ & & & & \\
\hline 17 & c5. & $\begin{array}{l}\text { Learning physics with LBQ's strategy makes me more } \\
\text { discipline in learning physics. }\end{array}$ & & & & \\
\hline 18 & c6. & $\begin{array}{l}\text { Learning physics with LBQ's strategy provides us } \\
\text { student-exchanges. }\end{array}$ & & & & \\
\hline
\end{tabular}

International Journal of Instruction, April $2019 \bullet$ Vol.12, No.2 